\title{
THE DEFENCE OF NECESSITY IN INTERNATIONAL LAW AND INVESTOR VERSUS STATE DISPUTE SETTLEMENT
}

\author{
Bader Bakhit M AlModarra * \\ College of Science and Theoretical Studies, Saudi Electronic University, Riyadh, Saudi Arabia, e- \\ mail: baderalmodarra@gmail.com
}

(Received: March 2019; Accepted: May 2019; Published: June 2019)

\begin{abstract}
The ability of foreign investors to sue host states without reliance on diplomatic protection is one of the most important developments in international investment law in the post-World War II era. The rise of investor-state dispute settlement under international regimes like the Convention Establishing the International Centre for the Settlement of Investment Disputes (ICSID Convention) raises some concerns from states regarding loss of sovereignty. However, there are defences available to states when they intervene in their economies for purposes like public utility or the need to safeguard an essential interest. Thus in spite of treaty commitments that bind states to protect the investments of foreign investors within their domains, there are available defences for their intervention in their economies even if such interventions become inimical to the interests of foreign investors and could, prima facie, raise the possibility of infringements of the rights of foreign investors. One of such defences available to states is the principle of necessity. This article explores the principle of necessity in international law and how it operates as a defence for states in investor-state dispute settlement. It also conducts analysis of the Annulment Decision in the CMS v Argentina case to shed light on the principle of necessity.
\end{abstract}

Keywords: Investor v State Dispute Settlement, Necessity Defence.

\section{The Defence of Necessity: A Historical Overview}

Under the necessity doctrine in international law, a conduct of state that violates an international obligation could still be justified if the rationale for the conduct is to avert a greater evil and hence produces a net societal gain [1]. Granville Williams expressed the necessity defence this way: "Some acts that would otherwise be wrong are rendered rightful by a good purpose, or by the necessity of choosing the lesser of two evils" [2]. The principle of necessity thus operates as a derogation

* Corresponding author: Bader Bakhit M AlModarra. E-mail: baderalmodarra@gmail.com

Copyright (C) 2019 The Author(s). Published by VGWU Press

This is an Open Access article distributed under the terms of the Creative Commons Attribution License - Non Commercial - NoDerivs License (http://creativecommons.org/licenses/by-nc-nd/3.0/) which permits unrestricted use, distribution, and reproduction in any medium, provided the original author and source are credited.

67 sciendo Journal of Legal Studies Volume 23 Issue 37/2019 ISSN 2457-9017; Online ISSN 2392-7054.

Web: publicatii.uvvg.ro/index.php/jls. Pages $67-82$ 
from a binding obligation under international law and by so doing justifies breaking the law when the obligation of preventing a harm outweighs the obligation to abide by the law. The necessity doctrine originated in English common law and over time has become a well-established principle.

In the arena of war, states are habitually reluctant to engage in outright violent aggression with each other, as this usually carries with it severe diplomatic and political consequences. Instead, states often prefer to resort to hostile measures short of war, such as reprisals and economic blockades or sanctions [3]. This hesitation to claim a right to warfare often results in invocation of the rhetoric of self-defence, necessity and self-preservation [4]. When a threat to self-preservation arises, it is considered justified to take any steps necessary to preserve one's existence, even if such steps would have been unlawful had they been taken in the absence of the threat to self-preservation [5]. States possess certain fundamental rights, including the right to existence and the attendant right to self-preservation. Writing in pre-World War II, Hershey for instance argued that in order to protect and preserve a State's right of existence, it may in extreme cases of necessity commit what would ordinarily be an infraction of the 'Law of Nations' and violate the territorial sovereignty or international right of another State [6]. The right to self-preservation was considered a subjective right of the invoking State and allowed for a more or less uninhibited use of force in situations where the security of the State was threatened [7]. The view was that, necessity knew no law and that States under certain, vaguely defined conditions, would be free to conduct themselves in accordance with their own self-interest.

One of the earliest decided cases regarding the necessity defence occurred in 1834. It concerned a mutiny in which the crew was justified in disobeying orders because they had a "bonafide reasonable belief" that the ship was unseaworthy [8]. Defendants in that case established that not just actual peril but a well-founded belief in impending peril is sufficient to raise the defence [9].

For Grotius, in the context of war, for example, when the exigencies of war makes it necessary for one power to occupy neutral soil if the enemy's occupation of that territory would pose a threat to its power, it may occupy the territory in the exercise of a right of necessity [10].

Rodick identified the following conditions inherent in the concept of necessity:

1. There must be an absence of mens rea on the part of one who exercises the alleged right of necessity.

2. There must be a real and vital danger, either to life, or to property.

3. The danger must be imminent in point of time.

4. In seizing the property of neutrals, the amount seized should be no greater than is necessary for the particular object in view.

5. Consideration must be given to the equities involved.

68 sciendo Journal of Legal Studies Volume 23 Issue 37/2019

ISSN 2457-9017; Online ISSN 2392-7054.

Web: publicatii.uvvg.ro/index.php/jls. Pages $67-82$ 
AlModarra, B.B.M., (2019)

6. The person who has exercised the right of necessity is bound whenever possible to make restitution or give an equivalent to the owner [11].

\section{The Modern Concept of Necessity}

Contemporary international law has partly responded to the earlier concept of necessity by dispensing with the notion of necessity as a right in favour of a notion that self-preservation and other "essential interests" may be used to "excuse" internationally wrongful conduct under certain limited circumstances [12].

The International Law Commission (ILC) has codified the modern concept of necessity under Article 25 of its Draft Articles on Responsibility of States for Internationally Wrongful Acts. Article 25 provides that:

1) Necessity may not be invoked by a State as a ground for precluding the wrongfulness of an act not in conformity with an international obligation of that State unless the act:

a) is the only means for the State to safeguard an essential interest against a grave and imminent peril; and

b) does not seriously impair an essential interest of the State or States towards which the obligation exists, or of the international community as a whole.

2) In any case, necessity may not be invoked by a State as a ground for precluding wrongfulness if:

a. The international obligation in question excludes the possibility of invoking necessity; or

b. The State has contributed to the situation of necessity [13].

\subsection{Essential Interest}

The invocation of necessity, in order to preclude the wrongfulness of conduct contrary to a State's international obligations, is first of all dependent on the identification of the essential interests of the State allegedly in the wrong [14]. In its Commentary, the ILC expressly referred to this distinction, stating that the "essential interest" requirement "does not mean that the Commission considered the interest in question to be solely a matter of the 'existence' of the State" [15]. The extent to which an interest is essential will have to be judged with consideration to the circumstances in the relevant case [16]. These interests however include, a State's "political or economic survival, the continued functioning of its essential services, the maintenance of internal peace, the survival of a sector of its population, and the preservation of the environment of its territory or a part thereof" [17]. The defence has been invoked in order to protect a wide variety of concerns, such as safeguarding the environment and ecological interests, grave financial difficulties, ensuring the safety of a civilian population and concerns for sound state finances and the ability to provide services and shelter to the State's nationals [18]. The International Court of Justice (ICJ) in the Gabčíkovo-Nagymaros Project case held that, “...with reference to State practice, 
AlModarra, B.B.M., (2019)

The defence of necessity in international law and investor versus state dispute settlement

ecological concerns over the past decades had evolved into being considered an essential interest" [19].

\subsection{Grave and Imminent Peril}

The determination of gravity and imminence of peril must be determined in casu and is highly fact-specific [20]. Boed opines that, any threat likely to destroy the possibility of realising an essential State interest constitutes 'grave peril' [21]. The ILC refers to 'imminent peril' as "a threat to the interest at the actual time. The ICJ in the Gabjikovo-Nagymaros Project case sought to further draw out the meaning of the terms. As to the 'imminence' of the peril, the Court observed that 'imminence' is synonymous with 'immediacy' or 'proximity' and goes far beyond the concept of possibility. The Court interpreted 'peril' as referring to danger in as much as it "evokes the idea of risk" rather than "material damage" [22].

One situation where the international community appears to have accepted the peril as sufficiently grave is the Torrey Canyon incident in 1967. A Liberian oil tanker went aground off the coast of Cornwall, with a cargo of 119,000 tons of crude oil. The collision tore a hole in the hull and within two days nearly 30,000 tons of oil leaked out, whereupon the UK Government ordered the bombing of the ship, in order to burn the remaining oil [23]. Although the UK never offered a legal justification for its action, the Government emphasised the extreme danger of the situation, and the lack of protests from governments or private parties appear to render support that the situation was indeed of such severity that extraordinary measures were warranted [24].

2.3 The Act must be the only Means Available to the State to Safeguard its Interest Consistent with the view that necessity justifies otherwise unlawful conduct only in the most exceptional circumstances, international law requires that the acting State must have no alternative but to engage in the unlawful conduct in order to protect its essential interest. The plea of necessity is excluded if there are other lawful means available to safeguard the essential interest of the State, a requirement that can be regarded as a function of the exceptional character of the plea of necessity [25]. The ILC in its commentary emphasized its strict understanding that "the only means" test implies that, the rule applies even if such alternative means are costlier or less convenient [26]. Additional costs is not in any way allowed to be a determinative factor in deciding on whether other means were available to the State. Means also implies not only unilateral action, but also cooperative efforts taken together with other States [27]. In the Gabjikovo-Nagymaros Project case, the ICJ held that, the cost of the possible alternatives to internationally unlawful conduct is not a determinative factor in evaluating whether the unlawful conduct was the only means open to the State to protect its interests [28].

This criterion is one that is particularly difficult to fulfil, and consequently, many of the cases concerning necessity that exist in international law have turned on the

70 sciendo Journal of Legal Studies Volume 23 Issue 37/2019 ISSN 2457-9017; Online ISSN 2392-7054.

Web: publicatii.uvvg.ro/index.php/jls. Pages $67-82$ 
AlModarra, B.B.M., (2019)

The defence of necessity in international law and investor versus state dispute settlement

issue of the availability of alternative means. In the Pacific Fur Seals Arbitration the validity of the plea of necessity in international law was affirmed in support of the impossibility of averting danger with other means [29]. Thus, the Russian Government was justified in issuing a decree prohibiting sealing in an area which was indisputably part of the high seas [30]. However, the importance of the criterion of 'only means available' was reaffirmed more recently in the ICJ's Advisory Opinion Concerning Legal Consequences of the Construction of a Wall in the Occupied Palestinian Territory. The Court concluded that:

".... in light of the material before it, the Court is not convinced that the construction of the wall along the route chosen was the only means to safeguard the interests of Israel against the peril which it has invoked as justification for that construction" [31].

\subsection{The Balance of Interests Involved}

For a State's claim of necessity to succeed the act in issue must not seriously impair an essential interest of another State towards which the obligation existed. This requirement involves the balancing of the competing interests of two States: on the one hand, the interest of the State which is invoking the defence of necessity and, on the other, the State which will suffer a harm to its interest as a result of the actions of the State invoking the necessity defence [32]. Thus, a plea of necessity can only be accepted when the interest protected by the violated obligation is of less significance than the essential interest invoked by the State at fault [33]. On a scale of importance, the interest sacrificed on the altar of necessity must be less important than the interest that is being protected by the justification of necessity.

The Torrey Canyon incident related above can serve as an example of a situation where the interest of preventing serious pollution was indisputably higher than the ship owner's subjective rights. Another example is the Corfu Channel case [34]. The case reaffirmed the principle of sovereignty and international order, allowing this to outweigh the need for action based on the justification of necessity. The ICJ held that the United Kingdom could not rely on any defences of self-protection or self-help, since between independent States, respect for territorial sovereignty is an essential foundation of international relations. Thus, the Albanian Government's complete failure to carry out its duties was a mitigating circumstance for the actions of the UK Government. However, its primary duty being to ensure respect for international law, the Court had to declare that the actions of the United Kingdom violated Albanian's sovereignty [35].

The second set of questions, referred to in the ILC's Draft Article 33(2), entails exceptions to the availability of the necessity defence under special circumstances. Thus, even when the first set of questions is resolved in favour of the violating State, the necessity defence will be unavailable where: (i) a peremptory norm of general international law is involved; (ii) no derogation clauses in the relevant 
AlModarra, B.B.M., (2019)

treaty exclude the possibility of invoking the necessity defence; or (iii) the State in question has contributed to the state of necessity [36].

\subsection{Peremptory Norms}

A state of necessity may not be invoked "if the international obligation with which the act of the State is not in conformity arises out of a peremptory norm of general international law [37].

Peremptory rules are defined, according to the International Law Commission, as "norms accepted and recognized by the international community of States as a whole as norms from which no derogation is permitted and which can be modified only by subsequent norms of general international law having the same character" [38]. The ILC did not provide a list of international norms of peremptory character beyond noting, as possessed of such character, the prohibition on the use of force against the territorial integrity or political independence of another State, genocide, and the killing of prisoners of war [39].

The contemporary view is that any use of armed force constituting assault on the sovereignty of another State indisputably comes within the meaning of the term aggression and as such is prohibited under Article 2(4) of the UN Charter. This provision, at least to the extent that it is coextensive with the concept of aggression, enjoys the status of jus cogens [40]. The International Law Commission accordingly is of the view that peremptory rules are so essential for the life of the international community that a State should not be allowed to breach such obligations, however acute a state of necessity it faced [41].

\subsection{Non-Derogation Clauses in Treaty Provisions}

The second exception to the application of necessity arises when a treaty provision explicitly or implicitly excludes the possibility of invoking the state of necessity with respect to the breached obligation [42]. When a treaty contains a specific nonderogation provision, for example, it is clear that the drafters intended to preclude the availability of the necessity excuse for breach of the obligations enumerated in the provision [43]. In the case of a treaty that attaches no explicit non-derogation clause to any of its provisions, Draft Article 33's second exception is not conclusively disabled [44]. The ILC has cautioned that, "silence on the part of the treaty should not be automatically construed as allowing the possibility of invoking the state of necessity rather, the determination of whether a treaty implicitly precludes reliance on the state of necessity requires an inquiry into the object and purpose of the rule" [45]. The ILC has further argued that necessity must also be excluded as a defence, where it can be inferred from the text of the treaty that the use of necessity as a circumstance precluding wrongfulness would be in contradiction to the object and purpose of the treaty [46].

72 S sciendo Journal of Legal Studies Volume 23 Issue 37/2019 ISSN 2457-9017; Online ISSN 2392-7054.

Web: publicatii.uvvg.ro/index.php/jls. Pages $67-82$ 
AlModarra, B.B.M., (2019)

The defence of necessity in international law and investor versus state dispute settlement

\subsection{Contribution to the State of Necessity}

A State may not invoke the defence of necessity as a ground for precluding wrongfulness if the State has contributed to the situation of necessity or provoked, either deliberately or by negligence, the occurrence of the situation [47]. The contribution to the situation of necessity must not be merely incidental, but must imply sufficient substantial impact on the turn of events [48]. In the GabčíkovoNagymaros Project case, the ICJ held that, Hungary had helped, by act or omission, to bring about the situation of alleged necessity, therefore it could not now rely on that situation as a circumstance precluding wrongfulness [49].

\section{The Defence of Necessity in Investor v State Dispute Settlement}

The post-World War II era has witnessed a remarkable increase in global trade and economic activities. One of the resultant effects of this positive globalized economic interaction among states is the increase in foreign direct investment and bilateral investment treaties (BITs) which aim at protecting the rights and interests of foreign investors [50]. Public international Law uses multilateral and bilateral investment treaties as tools to protect and safeguard foreign direct investment. Contained in these treaties are mechanisms for settling disputes. One of such mechanisms is the investor-state dispute settlement (ISDS). ISDS when included in a treaty grants investors the right to seek remedies through prescribed dispute settlement mechanisms when they are of the view that the host state has breached their rights protected under the BIT. This form of dispute settlement relies more on arbitration than a formalistic court system [51].

Whereas trade disputes have antecedent in time immemorial, investment disputes are relatively new phenomena [52]. Investment disputes gained prominence the post-World War II era when foreign investments became lucrative. Post-World War II colonized states began fighting for their independence. This meant that nationals of the colonial states who had huge investments in the colonies had to deal with jurisdictions other than their national governments [53]. These newly independent states also encouraged investments from foreigners to jump start their economies. With such increase in foreign direct investment, it became necessary to protect the investors. This is because, investors feared that most of the newly independent states lacked the rule of law and did not acknowledge property rights. The real fear of the investors was against expropriation by the new governments, who would see a thriving foreign business as a lucrative means of generating income for the government.

There was a realisation on the part of the investors of the need to come out with principles and rules to protect foreign direct investments. A discussion was commenced amongst states of nationals with investments abroad under the auspices of the Organization for European Economic Cooperation [54]. Whilst the 
AlModarra, B.B.M., (2019)

The defence of necessity in international law and investor versus state dispute settlement

discourse was on-going globally, Germany and Pakistan took the initiative and attempted to offer investor protection through a bilateral treaty in 1959 [55]. The main aim of that agreement was to create favourable conditions for investments by nationals and companies of either state [56]. Included in these favourable conditions was protection against expropriation [57].

Another significant development that occurred with respect to investor protection was a multilateral agreement in 1965; the Convention on the Settlement of Investment Disputes between States and Nationals of other States [58]. The said Convention established the International Centre for Settlement of Investment disputes (ICSID) [59]. Article 25 of the Convention provides for the jurisdiction of ICSID. It states that:

"The jurisdiction of the Centre shall extend to any legal dispute arising directly out of an investment, between a Contracting State (or any constituent subdivision or agency of a Contracting State designated to the Centre by that State) and a national of another Contracting State, which the parties to the dispute consent in writing to submit to the Centre. When the parties have given their consent, no party may withdraw its consent unilaterally" [60].

ICSID provides an avenue for member states and nationals of member states to resolve any disputes that arises out of foreign direct investment. Since its inception, most BIT's have included in their texts, provisions that defer disputes to ICSID [61]. It has become more or less the de facto forum for the resolution of investment disputes.

In recent times, states have relied more and more on the doctrine of necessity in investor dispute settlements [62]. Argentina, in particular has on a number of occasions invoked the defence of necessity to justify breaches of investment treaties. Galvez argues that the investment tribunals have struggled to deal with the invocation of the necessity defence [63]. This can be attributed to the fact that necessity has rarely been used in investment treaties [64]. When necessity has been used in BIT's it has been used in two predominant capacities. According to BurkWhite and von Staden the doctrine has been used in investment treaties as a basis for balancing investor rights with a state actor's interests [65]. This is the first capacity. The second capacity according to McGrady is to distinguish between "legitimate regulatory choices" and illegitimate "excuses for protectionism." [66] Galvez argues that the application of the necessity doctrine in investment treaties has been modified [67]. She argues that the doctrine necessity does not take the same form as it does in customary international law. In trade and investment law, treaties such as BITs, the GATT and NAFTA have included provisions that provide a context before the application of the necessity doctrine [68]. International tribunals interpreting the necessity doctrine in investment disputes are driving the doctrine towards a broad framework [69].

74 sciendo Journal of Legal Studies Volume 23 Issue 37/2019 ISSN 2457-9017; Online ISSN 2392-7054.

Web: publicatii.uvvg.ro/index.php/jls. Pages $67-82$ 
AlModarra, B.B.M., (2019)

The defence of necessity in international law and investor versus state dispute settlement

In recent times, most BITs have incorporated necessity clauses [70]. This is because of the benefits it has, especially for "host nations". The doctrine of necessity when included in a BIT offers state actors the possibility of avoiding the negative consequences of breaching obligations in certain circumstances and thereby providing for consideration important state interests [71].

\section{The CMS v Argentina Case}

The case of CMS v Argentina [72] was part of a series of cases against Argentina following the measures taken by the then government in response to the economic and financial crisis it suffered between 1991 and 2001 [73]. This case was first tried by an arbitral tribunal of the International Centre for Settlement of Investment Disputes (ICSID) upon an application by CMS Gas Transmission Company. Based on findings made against Argentina regarding breaches of its obligations to CMS, it applied to the Adhoc Committee for an annulment of the decision of the arbitral tribunal.

The facts that brought the existence of this case before the Adhoc Committee are discussed below.

In the 1980s, in a quest to curb the economic hardships Argentina was facing, an economic recovery plan which consisted of privatizing government owned entities and public utilities was adopted and enforced.

CMS came into the picture when Transportadora de Gas del Norte (hereinafter referred to as TGN) was created as a result of the privatization of a state owned gas industry monopoly. CMS purchased $25 \%$ of the shares in TGN initially and later purchased $4.42 \%$ additional stake in TGN. Under the regime established by the laws and decrees pertaining to TGN, tariffs were to be calculated in dollars and then converted to pesos every 6 months according to the United States Producer Price Index (US-PPI).

The dispute originates from the economic hardships Argentina began to face at the end of the 1990s which led to certain changes in the economic structure of the country. In light of the hardship, the representatives of gas companies agreed to defer the US-PPI. That did not resolve the economic crisis and by 2001, the crises had intensified leaving Argentina with no option than to declare a state emergency. It revoked all the licenses of public utilities and companies to adjust tariffs according to its needs, the US-PPI was terminated and the tariffs were revised to 1 dollar to 1 pesto. This affected CMS greatly. In totality, Argentina had failed to adhere to its obligations under the BITS governing the transaction between the parties.

CMS applied to the ICSID for arbitration proceedings relating mainly to the decision taken by Argentina concerning the application PPI tariffs revision in the gas industry. The tribunal firstly stated that it had jurisdiction to entertain the 
AlModarra, B.B.M., (2019)

matter brought before it as it was within the jurisdiction and competence of the Tribunal. It went on to examine the substantial issue which was whether or not Argentina had breached its obligations to offer the investor fair and equitable treatment and fulfil its obligations under Article II(2)(a) and (c) of the Treaty [74]. Argentina argued that it should be excused from liability as it was faced with a situation of necessity envisaged in Article 25 of the ILC Draft Articles on State Responsibility. The tribunal rejected this argument as it was not satisfied that the condition being faced in Argentina met the necessity threshold under Article 25. It awarded costs to CMS. Argentina thus applied to the Adhoc Committee invoking the committee's powers to annul awards by the Tribunal. The grounds for annulment are, jnter alia, that:

a. The tribunal has manifestly exceeded its powers and

b. The award has failed to state the reasons on which it is based.

The main issue for the focus of this paper is whether or not the principle of necessity could afford the Argentina Republic exemption from liability for failure to fulfil its obligations?

Argentina argued, inter alia, that the Tribunal failed to take into account the economic hardship it was facing which created a situation of necessity thus allowing it to forego its obligations under the Treaty. It stated that the Tribunal erroneously interpreted Article XI of the Treaty [75] and Article 25 of the ILC Draft Articles. Argentina averred that the failure of the Tribunal to consider the argument on necessity resulted in the Tribunal exceeding its powers.

CMS, on its part, contended that the Tribunal's award should not be annulled as the Tribunal did not exceed its powers and did not fail to state the reasons for the award. Counsel for CMS stated that the Tribunal rightly rejected the arguments of Argentina on the principle of necessity as it did not meet the threshold provided under customary international Law.

The Adhoc Committee opined that the principle of necessity provided under Article 25 of the ILC Draft Articles is that of a customary international law principle, derogation of which will be met once a strict threshold has been met. Article 25 states:

"..." 1. Necessity may not be invoked by a State as a ground for precluding the wrongfulness of an act not in conformity with an international obligation of that State

unless the act:

(a) is the only way for the State to safeguard an essential interest against a grave and imminent peril; and

(b) does not seriously impair an essential interest of the State or States towards which the obligation exists, or of the international community as a whole.

76 Journal of Legal Studies Volume 23 Issue 37/2019 ISSN 2457-9017; Online ISSN 2392-7054.

Web: publicatii.uvvg.ro/index.php/jls. Pages $67-82$ 
AlModarra, B.B.M., (2019)

"Vasile Goldiş" Western University of Arad

The defence of necessity in international law and investor versus state dispute settlement

2. In any case, necessity may not be invoked by a State as a ground for precluding wrongfulness if:

(a) the international obligation in question excludes the possibility of invoking necessity; or

(b) the State has contributed to the situation of necessity." [76]

The Adhoc Committee drew a link between the essential interest stated in Article 25 and the situation in Argentina. It further linked article 25 to Article XI of the BIT which provides that;

"This treaty shall not preclude the application by either Party of measures necessary for the maintenance of public order, the fulfilment of its obligations with respect to the maintenance or restoration of international peace or security, or the protection of its own essential security interests."

It stated that this was not a self-judging clause and thus could be read in line with article 25 of the ILC Draft Articles. The Adhoc Committee was of the view that the Tribunal first determined that "there is nothing in the context of customary international law or the object and purpose of the Treaty that could on its own exclude major economic crises from the scope of Article XI." It added that "[a]gain, the issue is then to establish how grave an economic crisis must be so as to qualify as an essential security interest, a matter discussed above". To the Tribunal the economic crises faced in Argentina could have been fixed by other options than a foregoing of Argentina's duties under the BIT. The Tribunal did not however state how, why and to what extent these options should be met in the absence of which a denial of the benefit under the necessity principle should prevail. The Committee stated that the decision of the Tribunal was based on a clear erroneous interpretation of the law and thus annulled the decision that Argentina failed to fulfil its obligations. It however could reverse the totality of the decision given by the Tribunal. In relation to the award, the Tribunal was of the view that even if the principle of necessity had been met, Argentina would still have been under a duty to pay compensation under Article 27 of the ILC Draft Articles. To the Tribunal, compliance with the obligation would re-emerge as soon as the circumstance precluding wrongfulness no longer existed, which is the case at present.

The Committee annulled the decision of the Tribunal relating to observance of Argentina's obligations entered into with regard to the investment guaranteed in Article II(2)(c) of the Treaty. All Other claims of Argentina Republic were dismissed.

This case typifies the invocation of necessity as a defence to the failure of state parties to fulfil their obligations under BITS in the ICSID regime. The case shows that the principle of necessity can be legitimately invoked as a defence by states in disputes with investors. This is however subject to a strict threshold that proves that 
AlModarra, B.B.M., (2019)

no other options existed for the state or that, to some extent, the options were not feasible. Even in situations where the necessity principle has been met, the state can still be held accountable once the prevailing circumstances requiring resort to the necessity principle no longer exists.

\section{Conclusions}

In international law, states bear responsibility for the performance of any wrongful acts that can be attributed to the state. However, as the discussion above shows, one of the important defences that may be available to a state is the principle of necessity. Although it offers an important defence to a state that has committed wrongful acts, there are stringent prerequisites attached to the necessity principle that impute its strict application. In relation to BITs, it can be concluded that arbitral tribunals are very much reluctant to admit a defence of necessity proffered by states for their wrongful acts. In sum, although the defence of necessity exists, its availability to states is largely restricted. CMS v Argentina is thus one of the few cases where the necessity defence has been pleaded successfully, albeit not at the tribunal stage, but rather through the annulment proceedings at ICSID.

\section{Acknowledgements}

The authors thank the anonymous reviewers and editor for their valuable contribution.

\section{Funding}

This research received no specific grant from any funding agency in the public, commercial, or not - for - profit sectors.

\section{Author Contributions}

The author conceived the study, carried out the literature review agenda and was responsible for the design, data collection, legislative analysis and case interpretation.

\section{Disclosure Statement}

The authors have not any competing financial, professional, or personal interests from other parties.

\section{References}

1. Abbott, R., Erixon, F., Ferracane, M.F. (2014). Demystifying Investor-State Dispute Settlement (ISDS), 5 ECIPE Occasional Paper.

78 S sciendo Journal of Legal Studies Volume 23 Issue 37/2019 ISSN 2457-9017; Online ISSN 2392-7054.

Web: publicatii.uvvg.ro/index.php/jls. Pages $67-82$ 
2. Boed, R. (2014). State of Necessity as a Justification for Internationally Wrongful Conduct, 3 Yale Human Rights and Development Journal 4.

3. Brownlie, I. (1963). International Law and the Use of Force by States, Oxford University Press, Oxford.

4. Burke-White, W.W., von Staden, A. (2010). Private Litigation in a Public Law Sphere: The Standard of Review in Investor-State Arbitrations, 35 YALE J. INT'L L. 283, 283-84.

5. Burleigh Cushing, R. (1928). The Doctrine of Necessity in International Law, Columbia University Press,.

6. Crawford, J. (2002). The International Law Commission's Articles on State Responsibility - Introduction, Text and Commentaries, Cambridge University Press.

7. Gross, O., Ni Aolain, F. (2001). Emergency, War and International Law Another Perspective, 70 Nordic Journal of International Law 3.

8. Grotius, H. (1929). De Jure Belli Ac Pacis, Francis W. Kelsey trans., Oxford Clarendon Press.

9. Hershey, A.S. (1927). The Essentials of International Public Law and Organization, Macmillan Company, New York.

10. International Law Commission, Draft Articles on Responsibility of States for Internationally Wrongful Acts, November 2001, Supplement No. 10 (A/56/10), article 25 .

11. Okowa, P. (1999). Defences in the Jurisprudence of International Tribunals, in G. S. Goodwin-Gill and S. Talmon, The Reality of International Law; Essays in Honour of Ian Brownlie, Oxford University Press.

12. Salmon, J.A. (1984). Faut-il codifier l'état de nécessité en droit international, in J. Makarczyk, (ed.), Essays in Honour of Judge Manfred Lachs, Martinus Nijhoff.

13. Simeone, J.J. (2001). Survivors of the Eternal Sea: A Short True Story, 45 Saint Louis University Law Joutnal,1140-1141.

14. Simma, B. (2001). The Work of the International Law Commission at Its FiftyThird Session, 71 Nordic Journal of International Law 129.

15. Williams, G. (1957). The Sanctity of Life and The Criminal Law, Cambridge University Press.

16. *** International Law Commission, Draft Articles on Responsibility of States for Internationally Wrongful Acts, November 2001, Supplement No. 10 (A/56/10). 17. ***Addendum to the Eighth Report on State Responsibility, by Mr. Roberto Ago, U.N. Doc. AICN.4/318/ADD.5-7.

18. ***Report of the ILC (1980), UN Doc. A/35/10.

19. ***Yearbook of the ILC, 1980, vol. I, 1618th meeting, 182-3. 
AlModarra, B.B.M., (2019)

The defence of necessity in international law and investor versus state dispute settlement

20. ***Advisory Opinion Concerning Legal Consequences of the Construction of a Wall in the Occupied Palestinian Territory, International Court of Justice (ICJ), 9 July para. 56.

21. ***Report of the International Law Commission on the Work of its ThirtySecond Session, U.N. Doc. A/35/10, 1980.

\section{Notes}

[1] Joseph J. Simeone, 'Survivors of the Eternal Sea: A Short True Story', 45 Saint Louis University Law Joutnal, 2001,1140-1141.

[2] Glanville Williams, The Sanctity of Life and The Criminal Law (Cambridge University Press, 1957, 198.

[3] O. Gross, F. Ni Aolain, 'Emergency, War and International Law - Another Perspective', 70 Nordic Journal of International Law 3, 2001.

[4] Ian Brownlie, International Law and the Use of Force by States, Oxford University Press, 1963, 41.

[5] Roman Boed, 'State of Necessity as a Justification for Internationally Wrongful Conduct', 3 Yale Human Rights and Development Journal 4, 2014. ([hereinafter Boed).

[6] Amos S. Hershey, The Essentials of International Public Law and Organization, New York, Macmillan Company, 1927, 232.

[7] Faber Case, German-Venezuelan Mixed Claim Commission, X RIAA, 1903, 438 , at 466.

[8] United States v. Reed, 86 F. 308 (C.C.S.D. N.Y. 1897).

[9] Ibid.

[10] Hugo Grotius, De Jure Belli Ac Pacis, Francis W. Kelsey trans., Oxford Clarendon Press, 1929, Bk. II, para. XII.

[11] Rodick Burleigh Cushing, The Doctrine of Necessity in International Law, Columbia University Press, 1928, 5-6. (hereinafter Rodick).

[12] Boed, op cit, footnote 5, at 6.

[13] International Law Commission, Draft Articles on Responsibility of States for Internationally Wrongful Acts, November 2001, Supplement No. 10 (A/56/10), article 25. (hereinafter ILC Draft Articles).

[14] Bruno Simma, 'The Work of the International Law Commission at Its FiftyThird Session', 71 Nordic Journal of International Law 129, 2001. (hereinafter Simma).

[15] Boed, op cit, footnote 5, at 15.

[16] Phoebe Okowa, 'Defences in the Jurisprudence of International Tribunals', in G. S. Goodwin-Gill and S. Talmon, The Reality of International Law; Essays in Honour of Ian Brownlie, Oxford University Press, 1999, 402.

80 sciendo Journal of Legal Studies Volume 23 Issue 37/2019 ISSN 2457-9017; Online ISSN 2392-7054.

Web: publicatii.uvvg.ro/index.php/jls. Pages $67-82$ 
[17] Addendum to the Eighth Report on State Responsibility, by Mr. Roberto Ago, U.N. Doc. AICN.4/318/ADD.5-7, para 2.

[18] French Company of Venezuela Railroads case (France v. Venezuela), FrenchVenezuelan Mixed Claims Commission, X RIAA, 1902, 285.

[19] Report of the ILC (1980), UN Doc. A/35/10, para. 14.

[20] Boed, op cit, footnote 5, at 28.

[21] Ibid.

[22] Gabčíkovo-Nagymaros Project case (Hungary v. Slovakia), Judgment, ICJ Rep. 1997, 7, at 41-2, para. 54.

[23] Yearbook of the ILC, 1980, vol. I, 1618th meeting, 182-3, para. 41.

[24] Report of the ILC (1980), UN Doc. A/35/10, 82.

[25] John Crawford, The International Law Commission's Articles on State Responsibility - Introduction, Text and Commentaries, Cambridge University Press, 2002, 184. (hereinafter Crawford).

[26] Gabčíkovo-Nagymaros Project case, ICJ Rep. 1997, 7.

[27] Simma, 314.

[28] Gabikovo-Nagymaros Project, paras 55-57.

[29] Report of the ILC (1980), UN Doc. A/35/10, 82.

[30] Ibid.

[31] Advisory Opinion Concerning Legal Consequences of the Construction of a Wall in the Occupied Palestinian Territory, International Court of Justice (ICJ), 9 July para. 56.

[32] Jean A. Salmon, 'Faut-il codifier l'état de nécessité en droit international', in J. Makarczyk, (ed.), Essays in Honour of Judge Manfred Lachs, Martinus Nijhoff, 1984, 255.

[33] Report of the ILC (1980), UN Doc. A/35/10, para. 35.

[34] Corfu Channel Case (United Kingdom v. Albania); Assessment of Compensation, 15 XII 49, International Court of Justice (ICJ), 15 December 1949

[35] Ibid, at 35 .

[36] ILC Draft Article 33(2).

[37] ILC Draft Article, art. 33(2)(a).

[38] Report of the ILC (1980), UN Doc. A/35/10, para 37.

[39] Report of the International Law Commission on the Work of its Thirty-Second Session, U.N. Doc. A/35/10 (1980), para 37.

[40] Case Concerning Military and Paramilitary Activities in and Against Nicaragua (Nicaragua v. United States of America); Merits, International Court of Justice (ICJ), 27 June 1986, 14, at 153.

[41] Report of the ILC (1980), UN Doc. A/35/10, 107, para. 37.

[42] ILC Draft Article, article 33(2)(b).

[43] Boed, op cit, footnote 5, at 34. 
AlModarra, B.B.M., (2019)

The defence of necessity in international law and investor versus state dispute settlement

[44] Ibid, at 35.

[45] Report of the International Law Commission on the Work of its Thirty-Second Session, U.N. Doc. A/35/10, 1980, para 38.

[46] Report of the ILC (1980), UN Doc. A/35/10, para. 38.

[47] ILC Draft Articles, article 25.

[48] Crawford, op cit, footnote 25.

[49] Gabčíkovo-Nagymaros Project case, ICJ Rep. 1997, 7, at 46, para. 57.

[50] William W. Burke-White \& Andreas von Staden, 'Private Litigation in a Public Law Sphere: The Standard of Review in Investor-State Arbitrations, 35 YALE J. INT'L L. 283, 2010, 283- 84

[51] Roderick Abbott, Fredrik Erixon, and Martina Francesca Ferracane, Demystifying Investor-State Dispute Settlement (ISDS), 5 ECIPE Occasional Paper, 2014.

[52] ibid.

[53] ibid. 